\title{
FRANSA MİLLÎ KÜTÜPHANESİNDEKİ CÖNKLERDE ÂŞIK ÖMER ADINA KAYITLI ŞIIIRLER
}

\author{
Okt. Yıldıray ÇAVDAR \\ Selçuk Üniversitesi Türk Dili Bölümü \\ ycavdar@selcuk.edu.tr \\ ORCID ID: http://orcid.org/0000-0002-9846-0480
}

Öz

17. yüzyıl, Türk Halk Edebiyatı'nın gelişme seyri açısından bir dönüm noktası olarak kabul edilmektedir. Bu yüzyıl özellikle adeta saz şairlerinin yıldızlarının parladığı bir dönem olmuştur. Genelde çeşitli askerî sınıflar arasından yetiştiklerini bildiğimiz saz şairleri, orduyla birlikte İstanbul'a uzak serhat boylarında çeşitli mekânlarda ve meclislerde bulunmuşlar, halka hitap eden şiirler söylemişlerdir. Söz konusu yüzyılda âşık tarzı halk şiir denilince akla gelen üç büyük şair Karacaoğlan, Gevherî ve Âşık Ömer'dir. Her üç şair de halk arasında rağbet görmüş şiirleri beğeni toplamıştır. Özellikle bir divan tertip etmesi ve birçok nazım türünde şiir yazmasının yanı sıra şiirlerinin miktarı bakımından da mukayese edildiğinde Âşık Ömer'in diğer iki şaire göre ön plana çıktığını söyleyebiliriz. Türk saz şiirinin en büyük şairlerinden sayılan Âşık Ömer'in divanı 2010 yılında yayımlanmıştır. Söz konusu eserde şairin 1455 şiiri yer almaktadır. Ancak şairin 2000'den fazla şiirinin olduğu tahmin edilmektedir. Bu makalede Fransa Millî Kütüphanesinin Türkçe Yazmalar Bölümündeki mecmualar ve cönkler taranmış, cönklerde şairin yayımlanmış divanında bulunmayan on beş şiiri tespit edilerek Latin harflerine aktarılmıştır. Böylece Âşık Ömer'in divanına küçük de olsa bir katkı yapılmıştır.

Anahtar Kelimeler: Âşıłk Ömer Divanı, Âşşk Ömer, cönk, Türk saz şiiri.

\section{POEMS REGISTERED IN ÂŞIK OMER'S NAME IN THE CONKS AT THE FRENCH NATIONAL LIBRARY}

\section{Abstract}

The 17th century is regarded as a turning point with respect to the developmental process of the Turkish Folk Literature. That century was a period when especially minstrels were in the ascendant. Minstrels, or poet singers, who are known to have come from among various military classes, travelled together with the army to various places and gatherings far from Istanbul, addressed people and read poems. Three prominent poets from that period whose names spring to mind when it comes to folk poetry in the style of minstrels are Karacaoğlan, Gevherî and Âşı Ömer. All these three poets found favor with the public and their poems won recognition. We can say that Aşık Ömer comes into prominence compared to the other two poets especially due to the fact that he collected his poems in a divan, wrote poems in various kinds of verse and wrote amply. The divan of Aşık Ömer, who is regarded as one of the greatest of Turkish poet-singers, was published in the year 2010. The work in question contains 1455 poems of the poet. However, the poet is estimated to have more than 2000 poems. In this article, poetry journals and cönks at the Turkish Manuscripts Department of the French National Library (Bibliothèque Nationale de France) were investigated and in these cönks, fifteen poems of the poet which had not been included in his divan were found. These poems were transcribed in the Latin alphabet, thereby making a small contribution to Âşık Ömer's divan.

Keywords: Ashiq Ömer's Divan, Ashiq Ömer, cönk, Turkish poet-singers. 


\section{GİRIŞ}

17. yüzyıl âşık edebiyatı denilince akla gelen ilk şair diyebileceğimiz (Gevherî ve Karacaoğlan ile birlikte) Âşık Ömer; gerek yaşadığı dönemde gerekse günümüzde, saz şairlerinin üstadı kabul edilip âşık tarzı halk edebiyatımızın en üretken isimlerinden biri olarak bilinir. Kırımlı ya da Konyalı olduğuna dair görüşler olmakla birlikte yapılan son araştırmalarla onun Konyalı (Hadim ilçesinin Gezlevi köyünden) olduğu ispatlanmıştır. Ölüm tarihi yaklaşık 1707 yılına tekabül etmektedir (Karahan 1991: 1; Karasoy-Yavuz 2010: 72-82).

Çeşitli kaynaklarda iki binden fazla şiirinin olduğu belirtilen Âşık Ömer'in bir divan tertip etmesi, iyi bir eğitim almış olması, divan şairleriyle yarışacak derecede divan şiiri geleneğinde manzumeler kaleme alması, bir ordu şairi olarak o günkü Osmanlı coğrafyasının önemli bir bölümünü gezmiş olması kendisini edebiyat tarihimiz açısından önemli kılan hususların başında gelir (Karahan 1991: 1; Karasoy-Yavuz 2010: 16).

Şair'in önemini idrak eden ilk kişilerden biri Atatürk'tür. 1930'lu yıllarda Atatürk'ün Âşık Ömer'e duyduğu ilgi araştırmacıları bu konuda çalışmaya yönlendirecek önemli bir dürtü oluşturmuştu (Karasoy-Yavuz 2010: 65-66). Bu bağlamda 1935 yılında Sadettin Nüzhet Ergun Âşık Ömer Hayatı ve Şiirleri adlı eseri meydana getirmiş̧ir. Eserde şairin 666 şiirine yer verilmiştir. Ardından 1962 yılında Fuat Köprülü Türk Saz Şairleri adlı eserlerinde şair ve şiirleri hakkında bilgi vermiş̧tir. Bu çalışmalar sahasındaki boşluğu tam olarak doldurmadığı gibi S. N. Ergun'un çalışması şairin divanı olarak da algılanmıştır. Ayrıca bu alanda çalışacak olanları; Âşık Ömer'in divanına ya da şiirlerinin olduğu cönklere, şiir mecmualarına ulaşmadaki zorluklar, yazmaların tahriş ve tahrip olması, el yazılarının okunmasındaki güçlükler, çok sayıda şiirinin olması gibi sorunlar karşılamaktaydı. Âşık Ömer'e dair en son ve kapsamlı çalışma ise 2010 yılında Y. Karasoy ile O. Yavuz tarafından Asşı Ömer Divanı (bundan sonra ÂÖD) adlı eserle meydana getirilmiştir. Bu eserde şairin 1455 şiirine yer verilmiştir. Bununla birlikte söz konusu yayında da belirtildiği üzere şairin değişik cönk (Yavuz 1988) ve mecmualarda ÂÖD'de olmayan çok sayıda şiirinin olduğu bilinmektedir.

$\mathrm{Bu}$ makalede Bibliothèque Nationale de France (BnF) (Fransa Millî Kütüphanesi)'daki cönkler ve mecmualar taranmış, mecmualarda Âşık Ömer adına kayıtlı şiirlere rastlanmamıştır. Cönklerde ise Âşık Ömer adına kayıtlı pek çok şiire rastlanmış, yukarıda bahsedilen ÂÖD'de olmayan toplam on beş şiir tespit edilmiş, bunlar Latin harflerine aktarılmıştır. Makalenin sonuna şiirlerin eski harfli metinleri de verilmiştir. Metnin kuruluşunda ÂÖD'de uygulanan yöntem genel hatlarıyla esas alınmıştır. Her bir şiir için, tespit edildiği cönkün numarası ve varak numarası belirtilmiş, hemen altına şiirin Latin harfli metni verilmiştir. Bağlama ve vezne uymayan, yanlış yazıldığı düşünülen kelimelerde olabildiğince metin tamiri yapılıış, bu husus dipnotlarla belirtilmiştir. Tarafımızdan eklenen kelimeler ise köşeli ayraç içinde gösterilmiştir.

Bibliothèque Nationale de France (Bnf)'da Bulunan Cönklerde Âşık Ömer Adına Kayıtlı Şiirler

N845 1623 No.lu cönk: Adı geçen cönkte Âşık Ömer adına kayıtlı toplam dokuz şiir tespit edilmiş olup bunlardan ikisi ÂÖD'de yoktur. 574, 728, 796, 1015, 1438 No.lu şiirler küçük değişikliklerle; 288 No.lu şiir 2. dörtlüğü eksik olarak cönkte mevcuttur. Cöngün 1a sayfasında kayıtlı 1423 No.lu şiirin 3. dörtlügü eksik, 4. yani son dörtlüğü farklıdır. ÂÖD'deki 796 No.lu şiir, cöngün 3a sayfasında bazı farklılıklarla kayıtlı olup ilk dörtlüğü farklıdır. Adı geçen cönkte, ÂÖD'de olmayan iki şiir vardır (bk. 1 ve 2. şiirler).

N845 1624 No.lu cönk: Bu cönkte ÂÖD’deki: 177, 198, 254, 306, 665, 834, 843, 905, 945, 1135, 1176, 893, 994, 1033, 1036, 1202, 1407, 1445 No.lu şiirler olmak üzere toplam 18 şiir bazı değişiklikler ve eksiklerle mevcuttur. ÂÖD'de olmayan on iki şiir tespit edilmiştir (bk. 3-14. şiirler). 
N845 1627 No.lu cönk: Cönkte ÂÖD'deki 1368 No.lu şiir 5a sayfada bazı değişikliklerle mevcuttur.

N845 1630 No.lu cönk: ÂÖD'deki 303 No.lu şiir bir dörtlük fazladan olmak üzere bazı değişikliklerle 4a sayfasında mevcuttur. Cöngün 6a sayfasında ise ÂÖD'de olmayan bir şiir kayıtlıdır (bk. 15. şiir).

\author{
ÂÖD'de Olmayan Şiirler \\ 1. Şiir (BnF N845 1623: 3b) \\ Fâ'ilâtün Fâ'ilâtün Fâ'ilâtün Fâ'ilün \\ -.-- /-.--./ -.--- /-.- \\ Ey gönül dinle sözüm dildâr önünden şöyle dur \\ Yoluna fedâ bu canım dâr önünden şöyle dur \\ Gece gündüz benim işim dâimâ âh u figân \\ Bülbülem ben sen gülün gülzâr önünden şöyle dur \\ Bu hasretlik kâr eyledi bilmiş ol ki cânıma \\ Nazlı yârim rahm eyleyip gelmez oldu yanıma \\ Ceng ederdim adûlarla girme benim kanıma \\ Sevdiğim başın için ağyâr önünden şöyle dur \\ Varın söylen ol yârime hâtırımı yıkmasın \\ Derûnumda gizli sırrım hiç beyâna çıkmasın \\ Hüsn bağında açılmış anı nâdân kokmasın \\ Gerçi sen bir gonca gülsün hâr önünden, şöyle dur \\ Der ki Ömer sığınmıştır ol ganî Hudâ'sına \\ Kâil oldum bir gececik ol yârin odasına \\ Gelip yıkar kadîr değil bir binâ peydâsına \\ Çek elin sen kes ümidin mi'mâr önünden şöyle dur
}

\title{
2. Şiir (BnF N845 1623: 89b)
}

Fâ'ilâtün Fâ'ilâtün Fâ'ilâtün Fâ'ilün

-.-- /-.--./ -.--- /-.-

Üstâda hizmet edenler yol ile iz'ân bilir

Şeytâna tâlip olanlar dûzah-1 düzen bilir

Biri Tevrat biri Zebur İncil ü Kur'ân bilir

Dört kitabı hakk-içün okuyup yazan bilir

... ne hoştur kim bu cennet yapısı

Dört taraftan beri gelir bu cehennem kokusu

Yetmiş üç millet durur korku çeker hepisi

Ehl-i ârif olanın ilmini yazan bilir

Âşık-1 sâdık olanın kalbine ilhâm olur

Ol Hudâ'yı bilenler İblîs'i inkar bilür

Bağ-1la bostan bitirdi âkıbet ma' mûr olur

Devr edip devr-i fenâyı dolaşıp gezen bilir 
Der ki bu Âşık Ömer dert benim mihnet benim

Şükür ol Hudâ'ya söz benim sohbet benim

Yetmiş üç millettir cümlesi cennet dili

Varmayınca meydâna huzûr-1 mîzân bilir

\section{3. Şiir (BnF N845 1624: 17a)}

Bu şiirin vezni bozuk olup, Fâ'ilâtün Fâ'ilâtün Fâ'ilâtün Fâ'ilün şeklinde olması kuvvetle muhtemeldir.

Gitme cânım gel yok iktizâsı gurbetin

Bir karanlık gecedir yanmaz çırası gurbetin

Tutulursun bir daha kurtulması müşkül olur

Cilâsı hâlis demirdendir tuzağı gurbetin

Gece gündüz hep kahır yoldaş olur

Bir eli nâçârları sırrımın sırdaş olur

Döşeğin hâr yılan yastığın bir taş olur

Bundan rahat yatağı olmaz gurbetin

Dost olanin sözünü tut ey nev civân

Nâr-1 hasrettir ve gurbettir nevcivan mahlûk inan

Hışmılan kalkan yerinden âfet görür ziyân

Çün cehennemden başka olmaz bucağ gurbetin

4. Şiir (BnF N845 1624: 36b)

Fâ'ilâtün Fâ'ilâtün Fâ'ilâtün Fâ'ilün

-.-- /-.--./ -.--- /-.--

Ol tabibim etmedi derdime dermân akçesiz

Melhem edip vurmadı yarama [dermân] akçesiz

Bu zamâne dilberinde yok imiş asla vefâ

Çok aradım bulamadım bir tâze ben akçesiz

Gece gündüz her zaman aşkı söyledim

Sözümün aşkı budur ol sebepten söyledim

Derler idi gerçek imiş tecrîb eyledim

Teklîf ettim gelmedi hâneye bir an akçesiz

İptidâdan ben sana ${ }^{1}$ nâmdârım kaşı kemân

Anun için eyledim sırrımı ${ }^{2}$ cümle ayân

Pâyine yüz sürenlerin görmedim illâ aman

Bir gece [de] olmadı bağda mihmân akçesiz

Bilmedim ben âşık oldum bir vefâsız dilbere

Meyl edermiş ol dahi hem gayriye

Hep görenler dediler yazık bu Âşık Ömer'e

Bakmadı hiç yüzüme zülfü perîşân akçesiz

${ }^{1}$ Cönkte: seni

${ }^{2}$ Cönkte: sırrım 
5. Şiir (BnF N845 1624: 46a)

Fâ'ilâtün Fâ'ilâtün Fâ'ilâtün Fâ'ilün

-.-- /-.--./ -.-- /-.-

Ah edip devrân elinden gözlerim yaş incidir

Kadir kıymet bilmeyen yanında yoldaş incidir

Âşık isen âşıka gel nazâr eyle hâlime

Ehl-i kâmil olmayınca kötü söz baş incidir

Gâipten sundum destimi ban cevâhir kânına

Ehl-i diller bahâ biçsin la'line mercânına

Yüküm cevâhir yüküdür yıkmam boncuk yanına

Sarrâf olmayan bilmez ${ }^{3}$ sanır her taş incidir

Bahâr eyyâminda dinle ${ }^{4}$ bülbülün hengâmesin

Ağaçlar yaprağın dökmüş gümüş dağlar kimmesin

Herkeşin yaz eline vermiş alıknâmesin

Rûz-i kâsım gelince her kaşı kış incidir

Der ki Ömer bir yâr sordum halk içinde gizlice

Kaşı kara kirpik siyâh ala gözlüce

Kendi hûri soyu gılmân sanki melek yüzlüce

Kaşı siyâh kirpik siyâh ağzında diş incidir

\section{6. Şiir (BnF N845 1624: 50b)}

Fâ'ilâtün Fâ'ilâtün Fâ'ilâtün Fâ'ilün

-.-- /-.--./ -.--- /-.-

Hamdülillâh şol melek sîmâyı gördüm ben bugün

Pâyine yüzüm sürüp selâma durdum ben bugün

Ben gedâya vere Mevlâ'm şol güzelin vasfını

Rûhları gül lebleri kevseri gördüm ben bugün

Gül cemâlin seyr eden nice gitsin kârına

İsmi sultân yazılmıştır yüzünün güzârına

Her sabah kevkebi değer mektebin dîvârına

Salınıp mektebe gider ${ }^{5}$ bir güzel gördüm ben bugün

Ol benim nâzik efendim dediğim misillidir ${ }^{6}$

Cennetten çıkmış efendim gûyâ hûri mislidir

Nâz-1la söyler kelâmı bülbül mislidir

Hûri midir melek midir aslın sordum ben bugün

Kaddi tûbâya benzer gül yüzü günden ayân

Hûb cemâlin seyredenler ${ }^{7}$ aklını eyler ziyân

Der ki Ömer ismin yazsam kendini eyler nihân

\footnotetext{
${ }^{3}$ Cönkte: ne bilir

${ }^{4}$ Cönkte: dedik

${ }^{5}$ Cönkte: giderken

${ }^{6}$ Cönkte: mislidir

${ }^{7}$ Cönkte: Bu kelimeden sonra nice kelimesi vardı, atıldı.
} 
Lâkin lâ mim be fâ ile şu yâri gördüm bugün

\section{7. Şiir (BnF N845 1624: 61b)}

Fâ'ilâtün Fâ'ilâtün Fâ'ilâtün Fâ'ilün

-.-- /-.--./ -.--- /-.-

Ahdim olsun uğramayam yoluna deryâsına

Şeker olsan ağu derim balına deryâsına

Mevlâ selâmet verir çıkarırsa kıyıya bizi

Bir daha aldanır mıyım diline deryâsına

Hâlâ biz hâzırlanmadık nice cânlar hâzırlanır

Mevlâm selâmet verirse menzîlimiz hâzırlanır

Bunca sular hurûç eder bâtınında ${ }^{8}$ gizlenir

Nice ırmaklar karışır gölüne deryâsına

\section{8. Şiir (BnF N845 1624: 67a)}

Fâ'ilâtün Fâ'ilâtün Fâ'ilâtün Fâ'ilün

-.-- /-.--./ -.--- /-.-

Dünyânın vasfın sorarsan nûn-1 kâf üstündedir

Semânın çâr tarafı kûfî kâf üstündedir

Cihânın vasfın sorarsan eyleyim bir bir beyân

Arş-1 â’lâ-yı devrânda sağ taraf üstündedir

Ol Hudâ'nın âdetidir lâ ilâhî lâ yemûd ${ }^{9}$

Âdemi topraktan yarattı cisim verdi evvel vücûd

Makbûlü oldu Hudâ'nın melekler kıldı sücûd

Ol zamandan beri şeytân kem hilâf üstündedir

Der ki Ömer şu dünyâda toka bakma aça bak Hacılar hacca varanda zikreden huccâca bak Sevdiğim Rûnmân içinde bendegî muhtâca bak O Kâbenin cor yanı sağ taraf üstündedir

\section{9. Şiir (BnF N845 1624: 68b)}

Fâ'ilâtün Fâ'ilâtün Fâ'ilâtün Fâ'ilün

-.-- /-.--./ -.-- /-.--

Kân-ı nûrundan âlemi bünyâd eden Mevlâ mıdır

Kudretinden ins ü cinni halk eden Mevlâ mıdır

Ol Hudâ'ya âsî olup Âdem'e secde etmedi

Ol la'îni dergâhından tard ${ }^{10}$ eden Mevlâ mıdır

Yunus'u yuttu balıklar okurken evlâdını

Eyyûb'u yedi kurtlar bulmadılar dadını

Hak yoluna kurbân etti İbrâhim evlâdını

Koç koyunu İsmâil'e imdâd eden Mevlâ mıdır

\footnotetext{
${ }^{8}$ Cönkte: yanında

${ }^{9}$ Cönkte: yemûn

${ }^{10}$ Cönkte: redd
} 
Nefrûk erdi İbrâhim yakmayan Hâlık'ı gör

Göz açıp yummadan yol gösteren Hâlık'ı gör

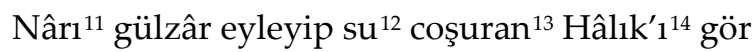

Bu işleri kâfire irşâd eden Mevlâ mıdır

Cümle kuşlar [ile] kurtlar bir araya geldiler

Gökyüzünden melâikler sâf sâf olup durdular

Der ki Ömer mucizât-1 Mustafâ'ya verdiler

Cümle peygâmberleri ${ }^{15}$ şâd eden Mevlâ mıdır

\section{0. Şiir (BnF N845 1624: 79b-80a)}

Fâ‘ilâtün Fâ'ilâtün Fâ'ilâtün Fâ'ilün

-.-- /-.--./ -.--- /-.-

Ey güzel âşığa cefâkâr imişsin anladım

Ben gül-i rânâ sanırdım hâr imişsin anladım

Neyleyim ey kaşı kemân cânıma kasd eyledin

Yâr sanırdım yâr değil ağyâr imişsin anladım

[Bu] zamâne dilberine kafadâr olmak da güç Ağlayıp bülbül misâl âh u zâr olmak da güç Hırkamız abâ deyip terk-i diyâr olmak da güç Âşığa rahm eylemez dildâr imişsin anladım

Ta geceler subh olanda yanarım pervâneyim İçmişim aşkın dolusun ${ }^{16}$ aşk ile mestâneyim Bu Ömer kulunu görsen ${ }^{17}$ dert ile divâneyim Akrânım olup sonrası inkâr imişsin anladım

\section{1. Şiir (BnF N845 1624: 84a-84b)}

Fâ'ilâtün Fấilâtün Fâ'ilâtün Fâ'ilün

-.-- /-.--.// -.-- /-.--

Aşk odundan hastayım dermâna minnet kalmadı

Kul olamam kimseye fermâna minnet kalmadı

Hudâ verir kısmetim her câna minnet kalmadı

Âlemin mâbûdusın merdâna ${ }^{18}$ minnet kalmadı

Oldu çırasında ... sızlarım

Bende dil yarası çoktur kimse bilmez gizlerim Ahdi bütün kavli sâdık şöyle bir yâr gözlerim Sezâvâr-1 Hudâ'yım insâna minnet kalmadı

İstedim derviş misâli eğnime şâl eyleyim

\footnotetext{
${ }^{11}$ Cönkte: nâr

${ }^{12}$ Cönkte: suları

${ }^{13}$ Cönkte: coşurup

${ }^{14}$ Cönkte: balığ1

${ }^{15}$ Cönkte: peygamberler

${ }^{16}$ Cönkte: dürlüsün (türlüsün)

${ }^{17}$ Cönkte: gören

${ }^{18}$ Cönkte: merde 
Satayım [bu] mâlı mülkü gönlümü̈ ${ }^{19}$ hoş eyleyim

Yâr elinden ab-1 kevser doldurup nûş eyleyim

Cenâb-1 Hudâ kerimdir ${ }^{20}$ câna minnet kalmadı

Yeri[n] göğü[n] şeş yerinin Hâlık'ı leyl-i nehâr

Seni inkâr edenin işi olsun âh u zâr

Der ki Ömer vermesin ol ganî Perverdigâr ${ }^{21}$

Senden uzak kabrimi sultâna minnet kalmadı

12. Şiir (BnF N845 1624: 85b)

$\mathrm{Bu}$ şiirde vezin tespit edilememiştir.

Emânet etmişin geldi selâmın

Mürüvvetli sultanım aleykümselâm ${ }^{22}$

Aldım ta'zim ile bir bir ${ }^{23}$ kelâmın

Derde dermânım aleykümselâm

Geçirdim boynuma aşkın kemendin

Adûlar çözmesin göğsünün bendin

Bilirim efendim insâfa geldin

Ey şâh-ı civânım aleykümselâm

Geçmişim uğruna cân ile tenden

Umarım efendim mürüvvet senden

Demişsin selâm et gedâya benden

Ey mâh-1 tâbânım aleykümselâm

Gine muhabbetin âşikâr ettin

Mesken-i ateşi gülistân ettin

Mahzûn Âşsk'1 şâdumân ettin

Ey nazlı hâbânım aleykümselâm

13. Şiir (BnF N845 1624: 86b)

$\mathrm{Bu}$ şiirde vezin tespit edilememiştir.

Kaşların lamelif gözlerin mim sâd

Muhabbetnamesiz yaz elden gitti

Vücûdum şehrini eyledin berbâd

Yıktın virân ettin can elden gitti

Selâm verip selâm alam der-iken

Yâr yoluna cânım fedâ der-iken ${ }^{24}$

Derdimin dermânın bulayım der-iken

\footnotetext{
${ }^{19}$ Cönkte: gönlüme

${ }^{20}$ Cönkte bu kelimeden sonra" her" kelimesi var, tarafımızdan çıkarıldı.

${ }^{21}$ Cönkte: vermezdim

${ }^{22}$ Cönkte: gönlüme

${ }^{23}$ Cönkte: bu ben

${ }^{24}$ Cönkte: cân fedâ eyleyen
} 
Derdimin dermânı tez elden gitti

Ferhadım zâr-1lan dağlar kırmaya

Mecnûnum ince belin sarmaya

Gönlümü göndürdüm yâr görmeye

Gönül eylencesi tez elden gitti

Âşık Ömer der ki öldüğüm zamâna

Çok nasihât ettim gelmez îmâna

Selâm eyleyin dostlar kaşı kemâna

Ağlaya ağlaya göz elden gitti

\section{4. Şiir (BnF N845 1624: 88b)}

$\mathrm{Bu}$ şiirde vezin tespit edilememiştir.

Efendim gûş edip dinle sözümü

Aşk dilinden bilir misin ne dersin

Bir kere olsun güldür yüzümü

Âşığa yâr olur musun ne dersin

Mansûr'un kemendi göğsümün ağ1

Ferhâd Şîrîn için deldi bir dağ 1

Eğlenmez geçer hûbların çağı

Böyle güzel kalır mısın ne dersin

Fânîdir şu dünyâ fânîdir derler

Yarın siyâset günüdür derler

Derdimin dermânı seni dediler

Derde dermân olur musun ne dersin

Bize dersen biz yâr-1 sâdıklarız

Muhabbeti cân içinde saklarız

Mecnûn gibi dağ başını bekleriz

Leylâ'm gine gelir misin ne dersin

Ömer eyder yaylaların yaylasam

Arz-1 hâl eylesem yâre söylesem

Abd-i şâkir olup hizmet eylesem

Kula sultân olur musun ne dersin

15. Şiir (BnF N845 1630: 4a)

$\mathrm{Bu}$ şiirde vezin tespit edilememiştir.

Uzaktan merhaba olmaz

Gel ey mestâne bakışlım

Sıva beyaz kollarını

Dola mestâne bakışlım

Seni gören seni onmaz 
Hayalin karşımdan gitmez

Padişahlar zulüm etmez

Kula mestâne bakışlım

Dileğim oldur ki Hak'tan

Bizi var eden yoktan

Bülbülün figânı çoktan

Güle mestâne bakışlım

Âş1k Ömer göne göne

Mislin gelmemiş cihâne

Her sözüme bir bahâne

Bula mestâne bakışlım

\section{SONUÇ}

17. yüzyıl, Türk Halk Edebiyatı'nın gelişme seyri açısından bir dönüm noktası olarak kabul edilmektedir. Bu yüzyılda âşık tarzı halk şiir denilince akla gelen üç büyük şair Karacaoğlan, Gevherî ve Âşık Ömer'dir. Her üç şair de halk arasında rağbet görmüş şiirleri beğeni toplamıştır. Özellikle bir divan tertip etmesi ve birçok nazım türünde şiir yazmasının yanı sıra şiirlerinin miktarı bakımından da mukayese edildiğinde Âşık Ömer'in diğer iki şaire göre ön plana çıktığını söyleyebiliriz. Âşık Ömer'in şiirlerinin 1455'i 2010 yılında Divan'ının yayımlanmasıyla derli toplu olarak Latin harflerine aktarılmıştı. Ancak iki binden fazla şiirinin olduğu tahmin edilen şairin birçok şiir mecmuası ve cönkte Divan'ında olmayan çok sayıda şiirinin olduğu bilinmektedir.

Bu çalışmada Fransız Milli Kütüphanesi (Bibliothèque Nationale de France)'nde bulunan mecmualar ve cönkler taranmış, Âşık Ömer adına kayıtlı şiirler tespit edilmiştir. Bu şiirlerden şairin yayımlanmış divanında bulunmayan on beşi Latin harflerine aktarılmıştır. Bazı şiirler gerek vezin gerekse anlam bakımından kusurludur. Biz elimizden geldiği kadar metin tamiri yapmaya çalıştık. Konuları itibariyle tespit edilen şiirlerin onu âşıkane, üçü sufiyane tarzda olup ikisi gurbet konuludur. Âşık Ömer bir ordu şairi olduğu için Osmanlı coğrafyasının pek çok yerini gezmiştir. Doğal olarak onun şiirlerinde gurbet teması önemli bir yer tutar. Yukarıda görüleceği üzere şair genelde aruz veznini tercih etmiştir. Halk şairi olmasına rağmen aruz vezniyle divan şiiri tarzında ve zaman zaman sufiyane söyleyişle şiirler yazmasında, medrese eğitimi almış olmasının önemli ölçüde etkisi olduğunu söyleyebiliriz. Tespit ettiğimiz şiirlerin çoğu remel bahrinin Fâ'ilâtün fâ'ilâtün fâ'ilâtün fâ'ilün veznindedir.

Benzer çalışmalar Türk edebiyatının en önemli saz şairlerinden biri olan Âşık Ömer'in şiir külliyatının ortaya konması açısından önemlidir. 


\section{SUMMARY}

The 17th century is regarded as a turning point with respect to the developmental process of the Turkish Folk Literature. Three prominent poets from that century whose names spring to mind when it comes to folk poetry in the style of minstrels are Karacaoğlan, Gevherî and Âşık Ömer. All these three poets found favor with the public and their poems won recognition. We can say that Aşı Ömer comes into prominence compared to the other two poets especially due to the fact that he collected his poems in a divan, wrote poems in various kinds of verse and wrote amply.

1455 of Âşı Ömer's poems were transcribed into Latin Alphabet when his divan was published in 2010. However, it is known that the poet, who is estimated to have more than two thousand poems, has numerous poems in various poetry journals and cönks which were not included in his divan.

In this study, poetry journals and cönks at the French National Library (Bibliothèque Nationale de France) were scanned and poems registered in Âşık Ömer's name were determined. Fifteen of these poems, which are not included in the poet's published divan, were transcribed in Latin alphabet. Some of these poems are flawed with respect to both rhythm (meter) and meaning. We tried to repair the texts to the best of our ability. As far as their themes are concerned, ten of the poems are of minstrel style whereas three are in Sufi style and two are about absence from home. Since Âşık Ömer was a military poet, he travelled through much of the Ottoman geography. Naturally, the theme of absence from home occupies a significant place in his poems. As can be seen above, the poet generally preferred the aruz meter. We can say that his education at madrasahs had a substantial influence on his writing poems in the aruz meter in the divan poetry (Ottoman classical poetry) and occasionally in the Sufi style although he was a minstrel. Many of the poems we found are in the Fâ'ilâtün fâ'ilâtün fâ'ilâtün fấ'iün meter of the remel bahr.

Implementation of similar studies is important in revealing the complete poems of Ashiq Omer, who is one of the most prominent poet-singers in Turkish literature. 


\section{KAYNAKÇA}

Bibliotheque Nationale De France (Fransa Millî Kütüphanesi). Türkçe Yazma Eserler Bölümü. N845 1623, N845 1624, N845 1627, N845 1630 No.lu cönkler.

ÇAĞBAYIR, Yaşar (2007). Ötüken Türkçe Sözlük. İstanbul: Ötüken Yayınları.

DEVELLIOĞLU, Ferit (2009). Osmanlıca-Türkçe Ansiklopedik Lügat. Ankara: Aydın Kitabevi.

ERGUN, Sadettin Nüzhet (1935). Âşık Ömer Hayatı ve Şiirleri. İstanbul: Semih Lütfi Matbaa ve Kitabevi.

KARAHAN, Abdülkadir (1991). "Âşık Ömer”. İslam Ansiklopedisi C. 4. İstanbul: Türkiye Diyanet Vakfı Yayınları. 1.

KARASOY, Yakup-YAVUZ, Orhan (2010). Asşık Ömer Divanı. Konya: Ocak Grafik Tasarım.

KÖPRÜLÜ, Fuad (1962). Türk Saz Şairleri. Ankara. Milli Kültür Yayınları.

Şemseddin Sami (1899). Kâmûs-ı Türkî. İstanbul. İkdam Matbaası.

Türk Dil Kurumu (2012). Yazım Kılavuzu. Ankara: TDK Yay.

YAVUZ, Orhan (1988). "Türk Edebiyatında Cönkler, Hususiyetleri ve Dili". Türk Dünyası Araştırmaları (54): 117-131. 


\section{EKLER}

\section{ESKİ HARFLI METINLER:}

1. Şiir

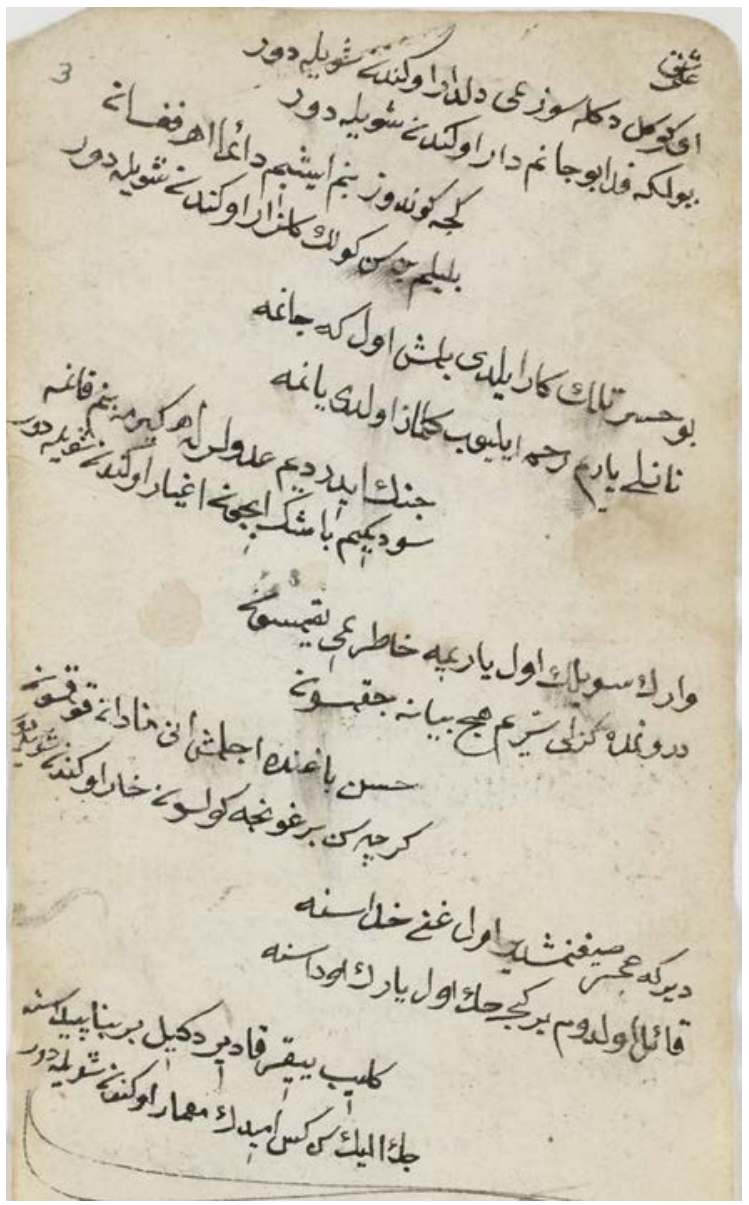

2. Şiir

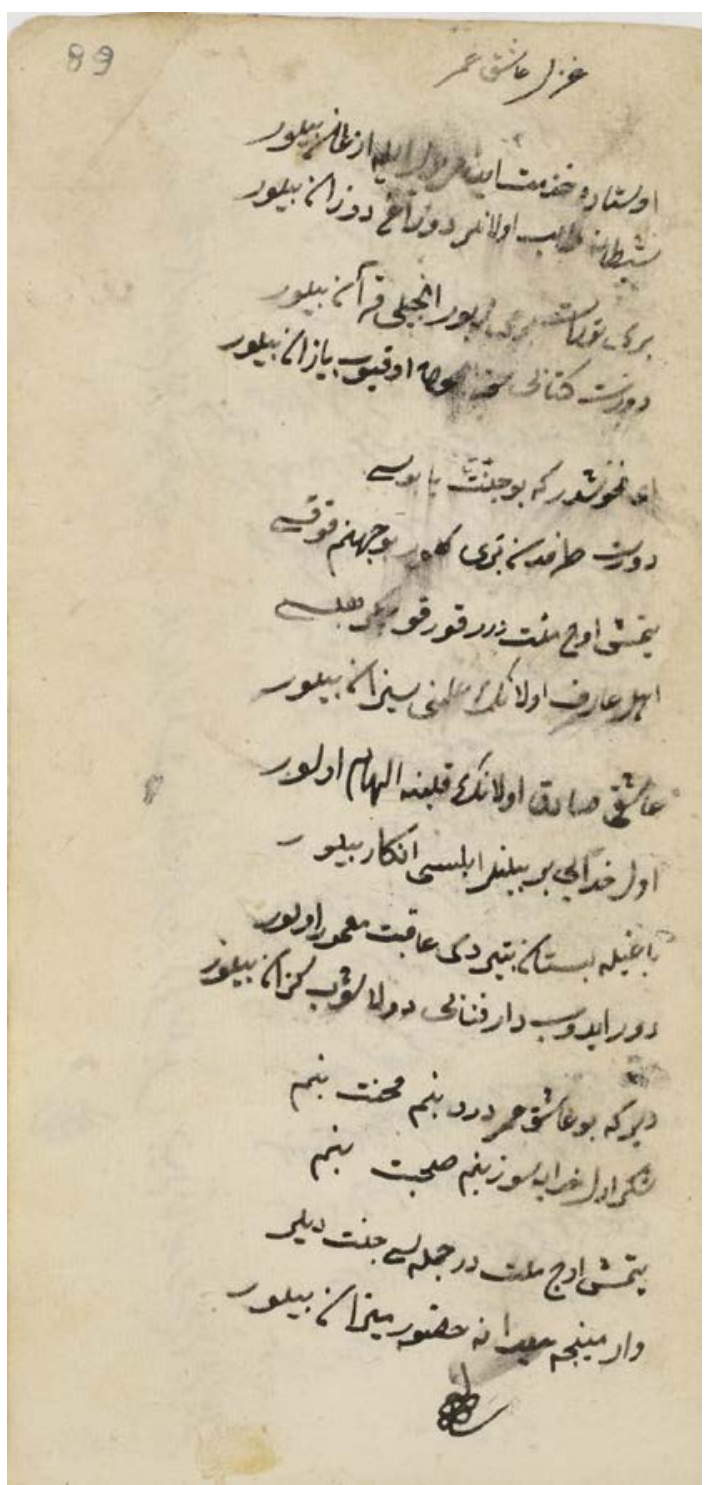


3. Şiir

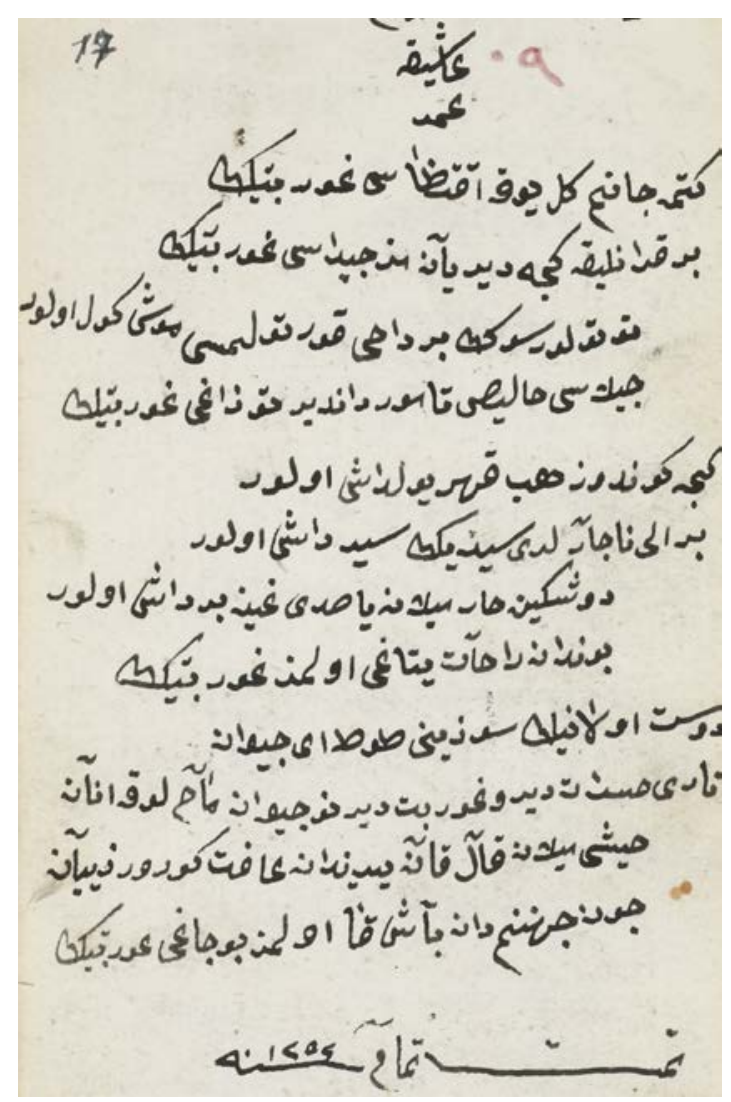

4. Şiir

$$
\text { كأن }
$$

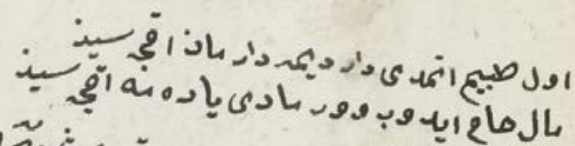

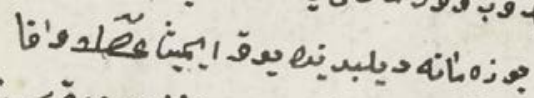

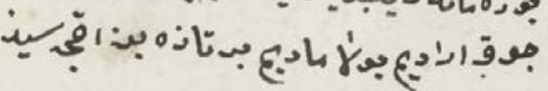

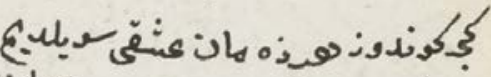

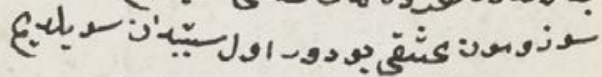

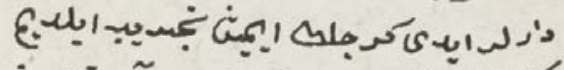

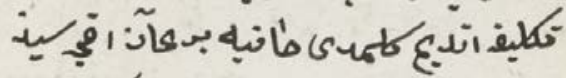

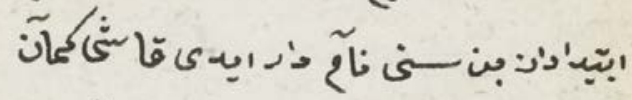

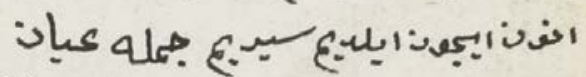

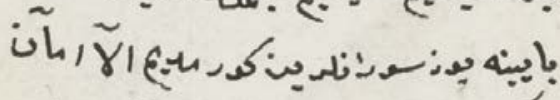

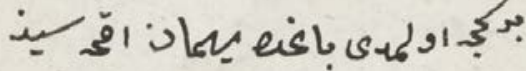

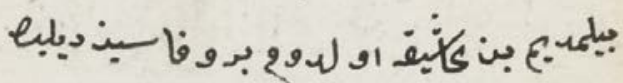

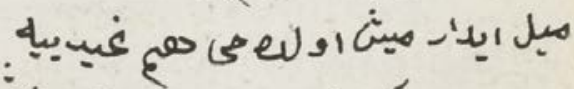

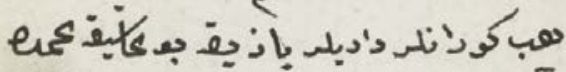

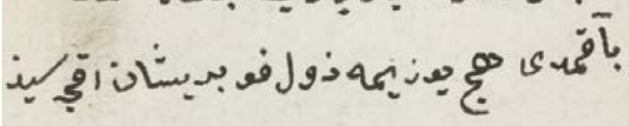

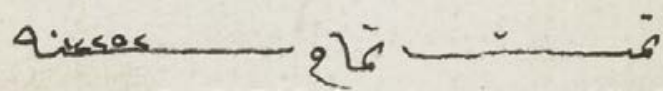


5. Şiir
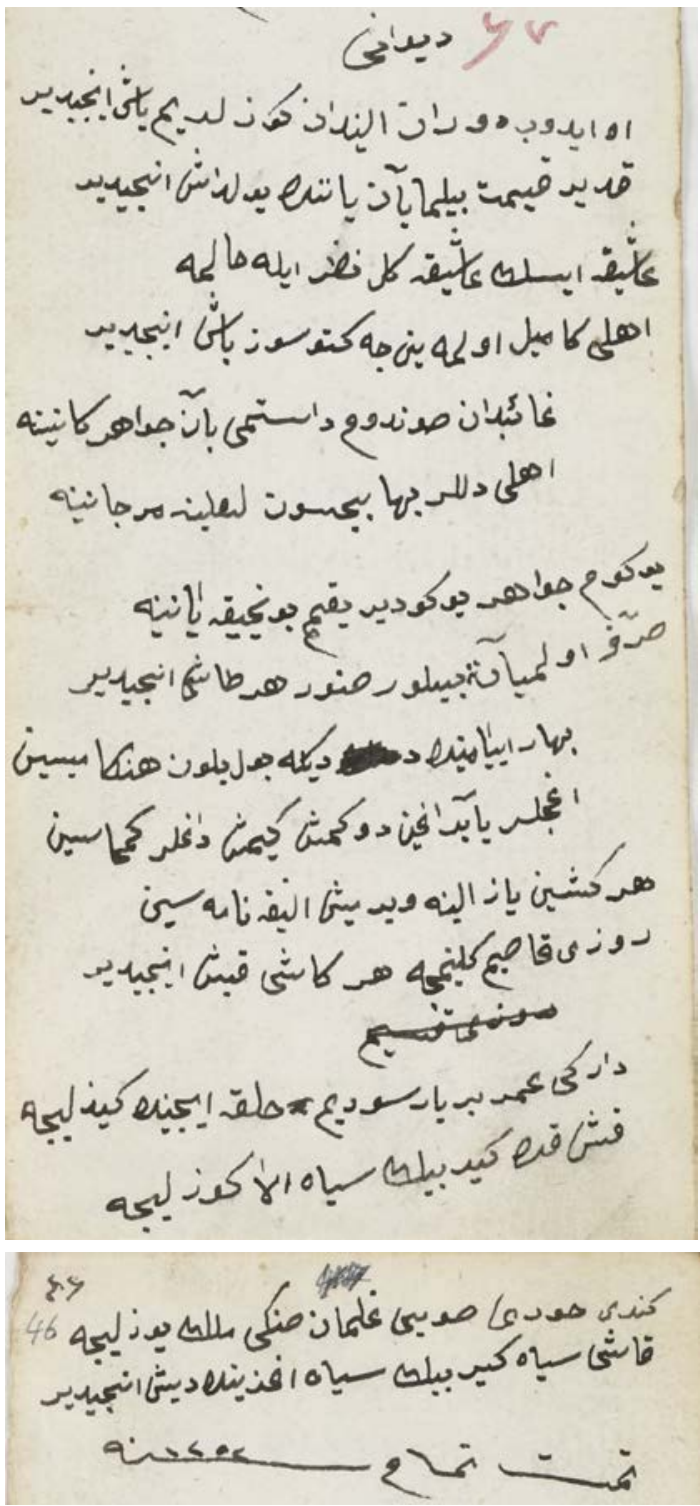

7. Şiir

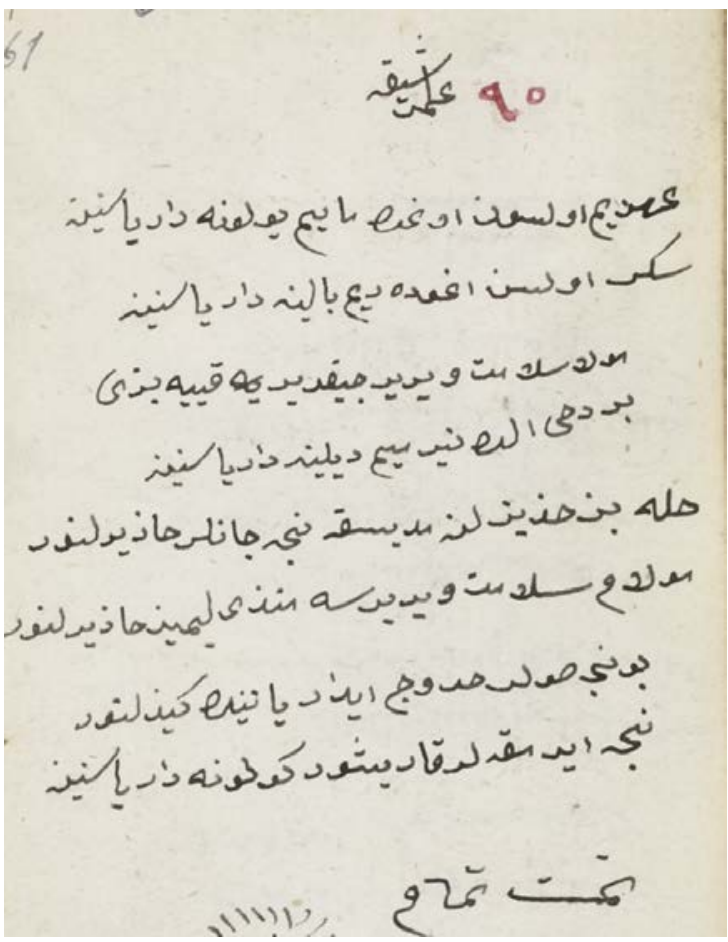

\section{6. Şiir}



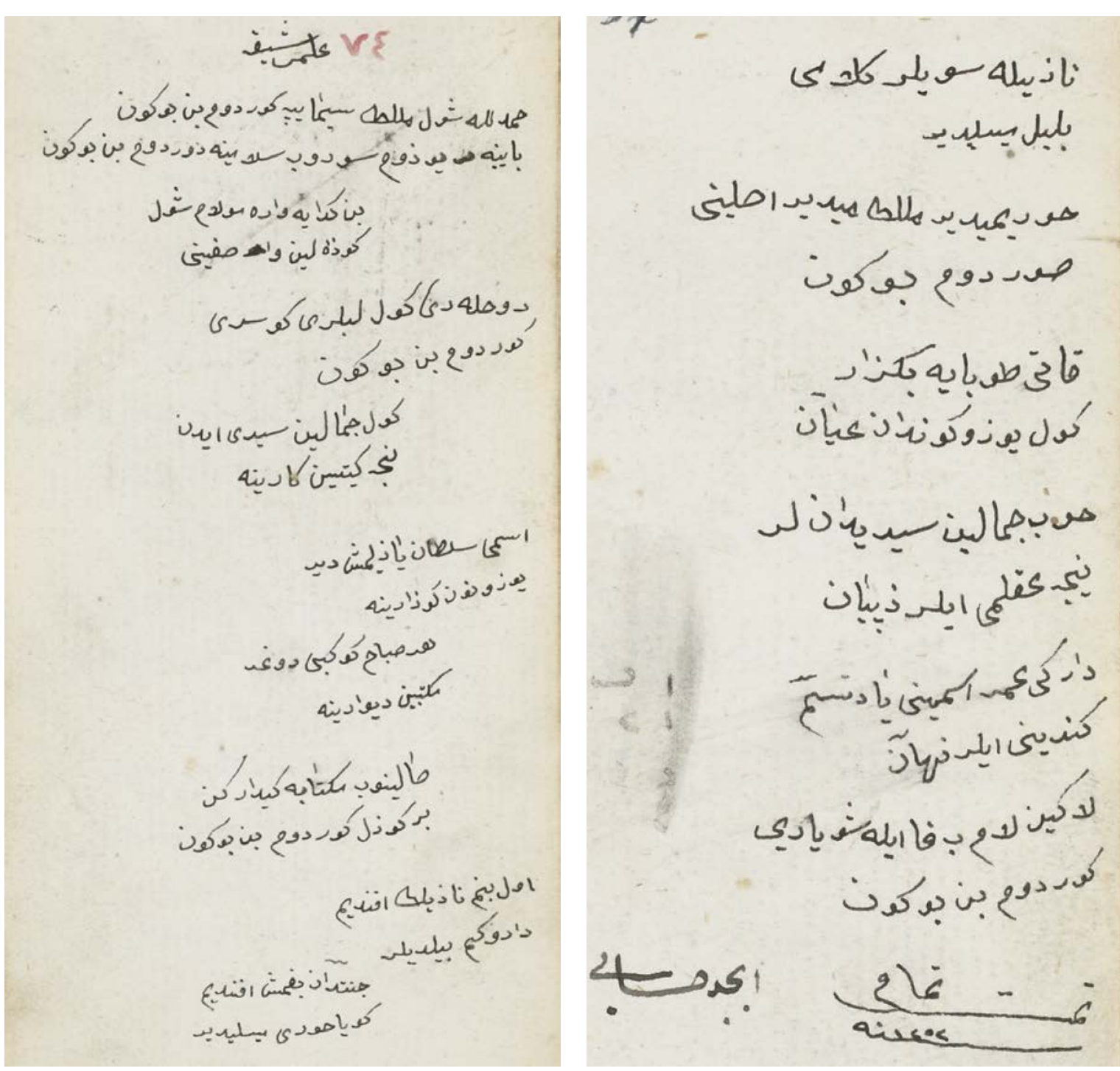
8. Şiir

\section{$67 \quad 48$}

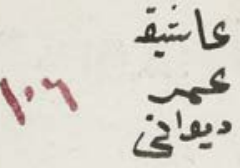

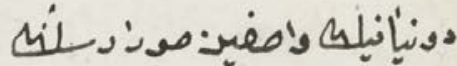
مغ

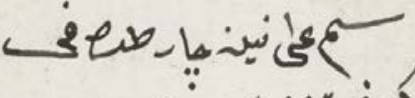

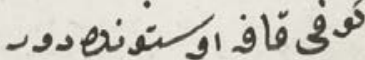

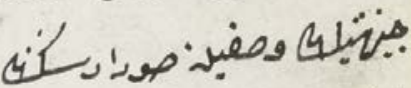

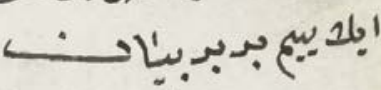

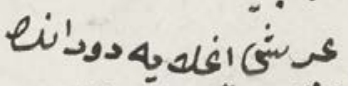

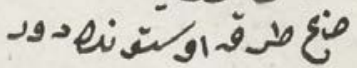

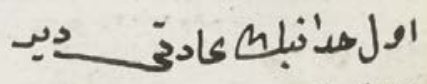

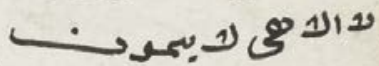

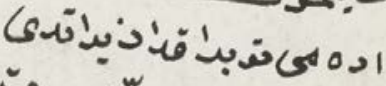

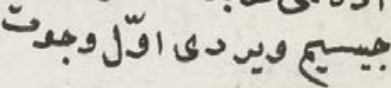

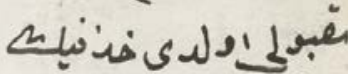

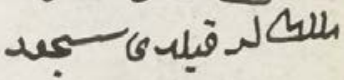

اونان

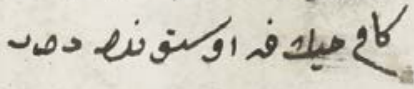

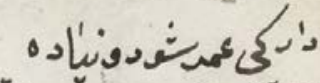

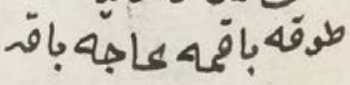

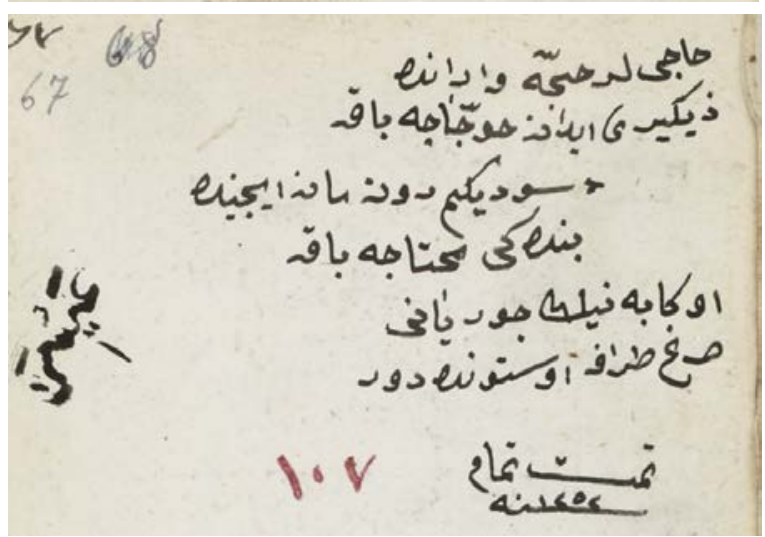

9. Şiir

\section{9 كs}

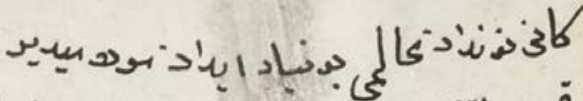
قوددئسنا

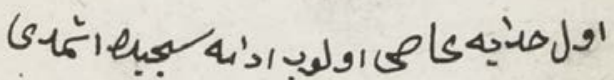

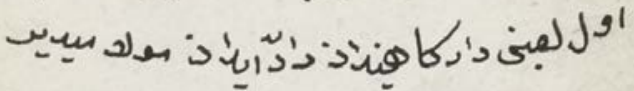

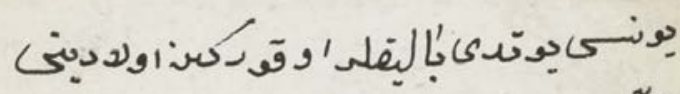

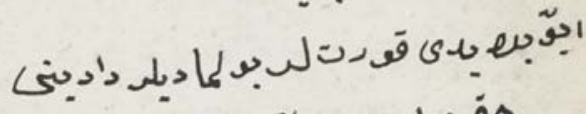

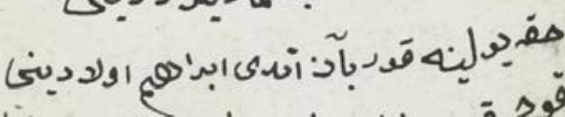

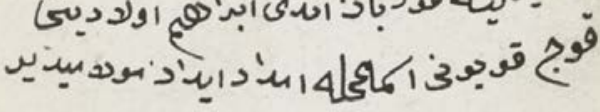

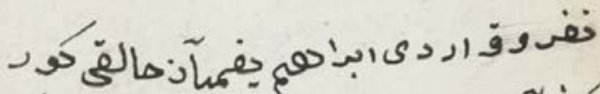

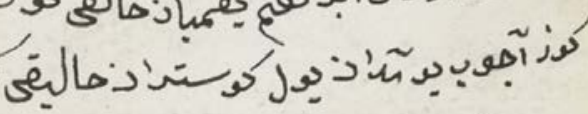

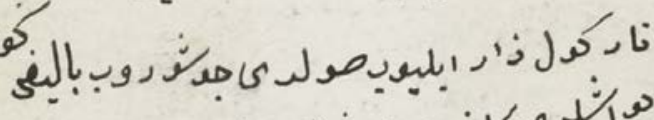

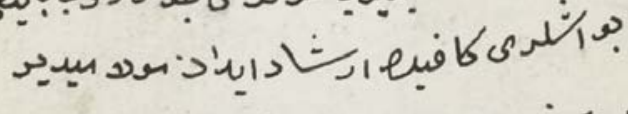

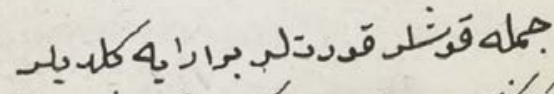

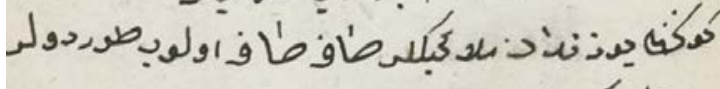

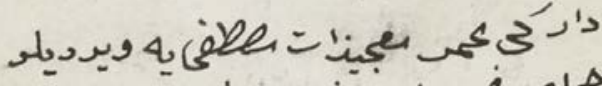

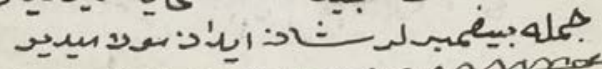
นrinarianos 
Yıldıray ÇAVDAR

404

10. Şiir

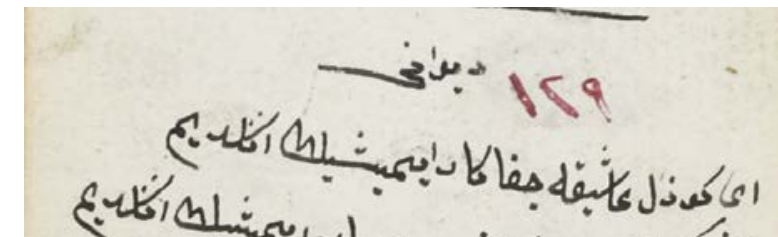

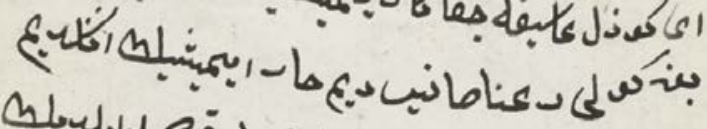

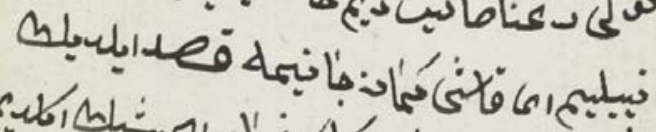

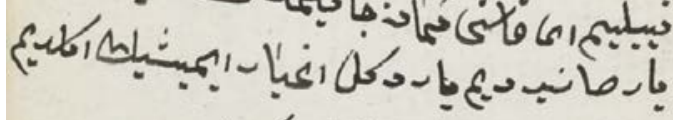

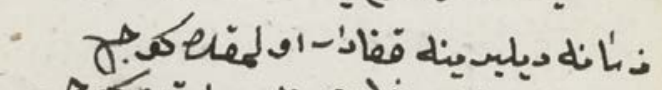

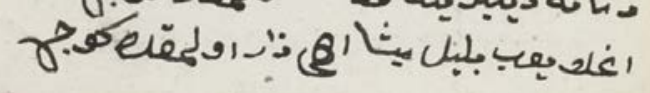

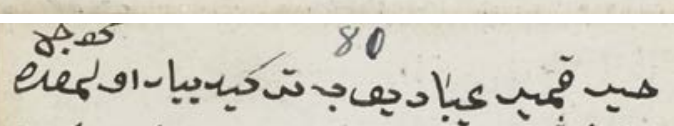

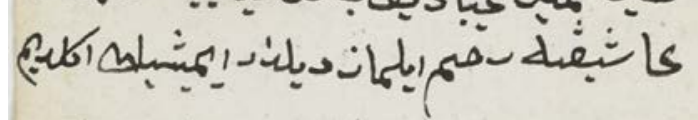

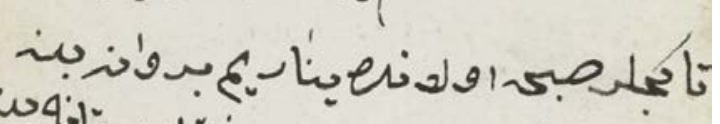

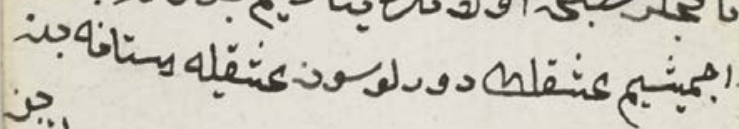
(20)

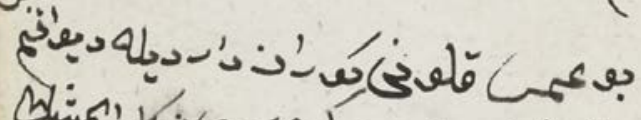

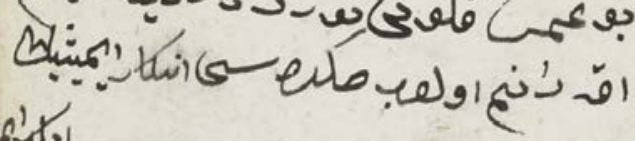
إن

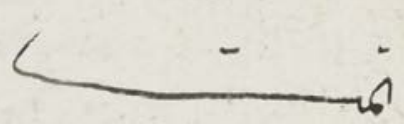

11. Şiir

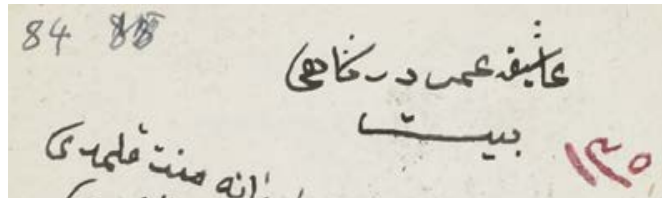

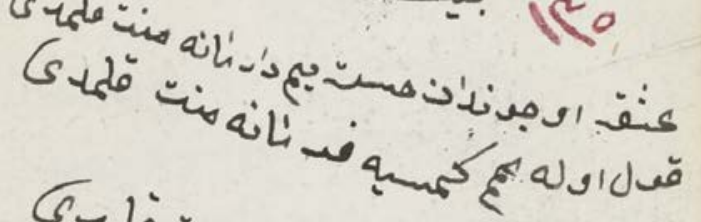

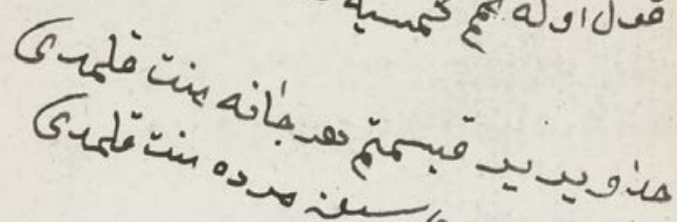

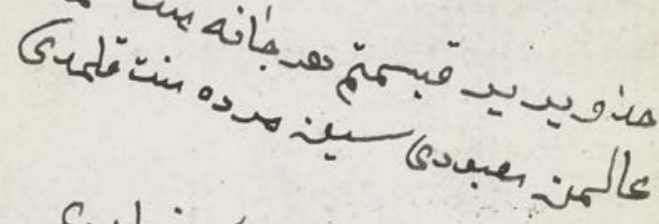
וو

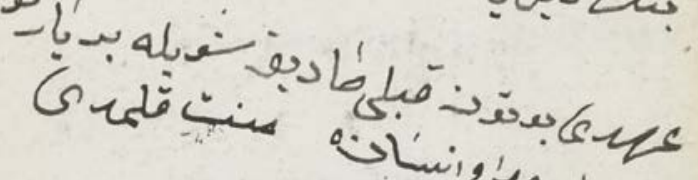
Gristis

ही

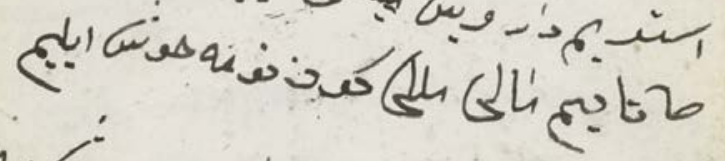

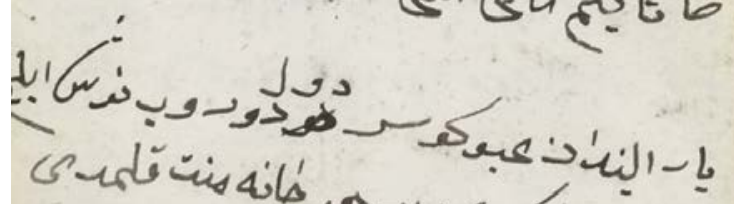

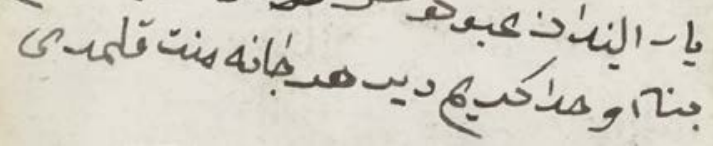

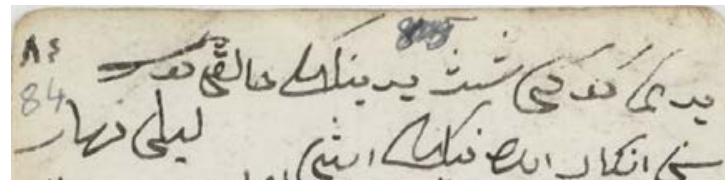

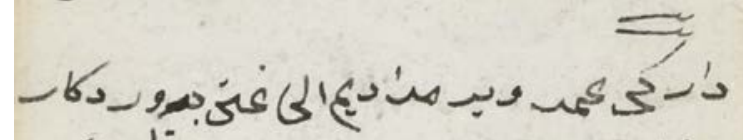
Grin

SEFAD, 2017 (37): 387-406 
12. Şiir

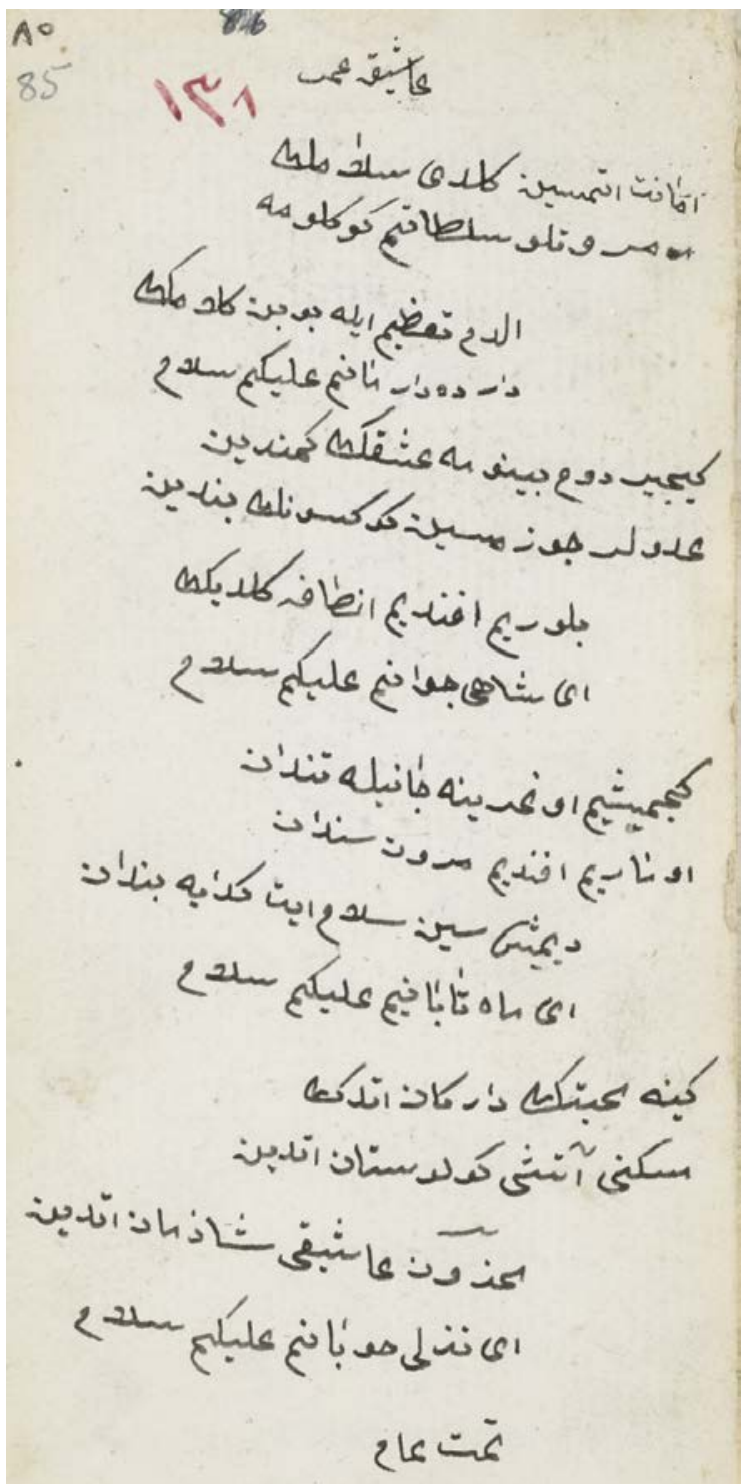

13. Şiir

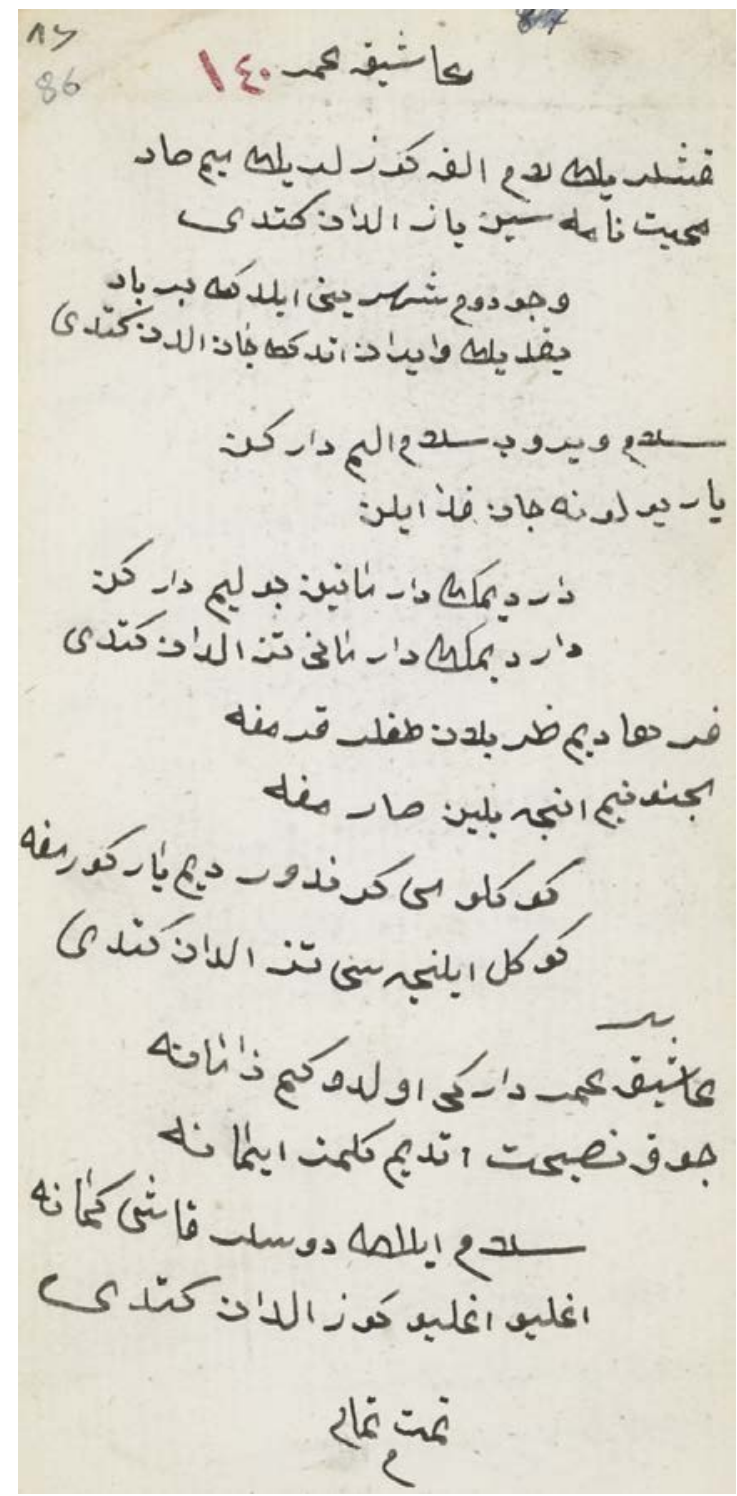


14. Şiir

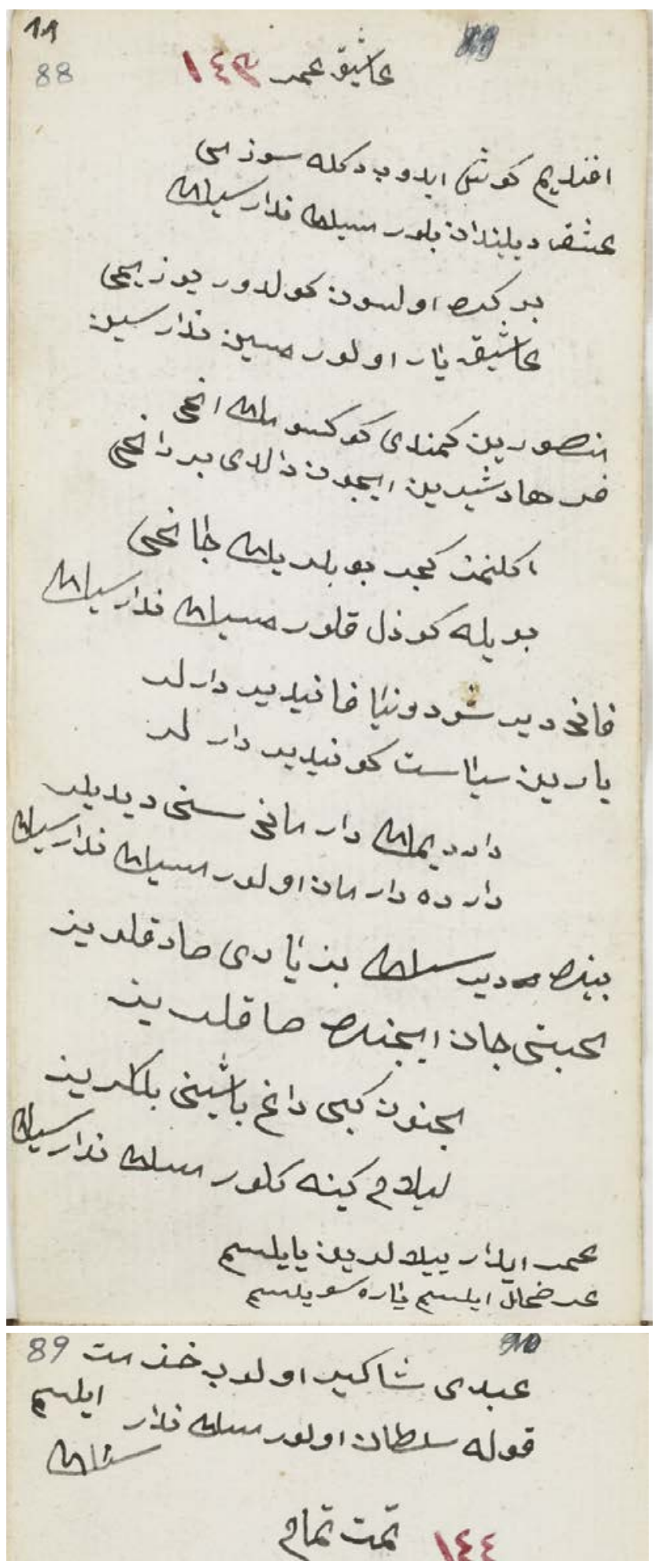

15. Şiir

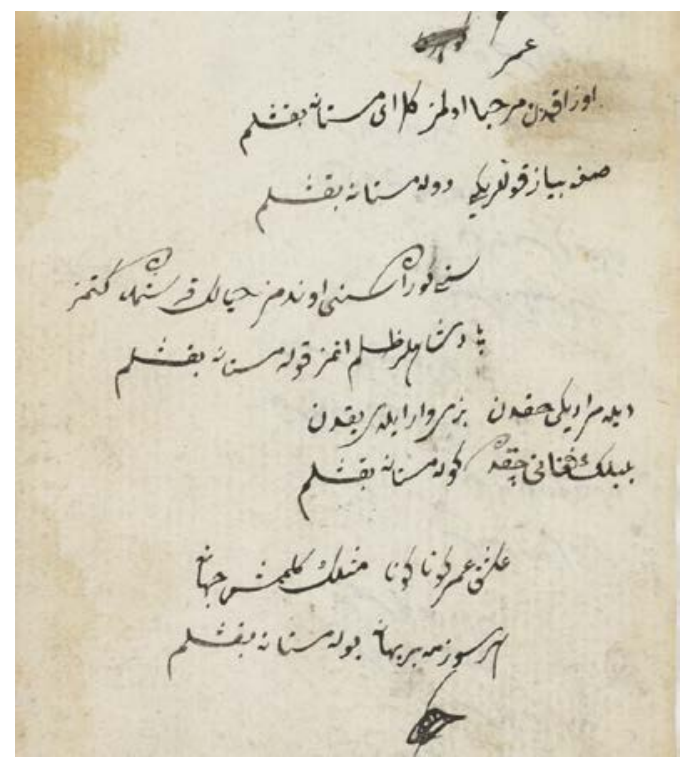

